\title{
Exploring the Use of "Chinese Elements" in Dance Sport from the Perspective of Cultural Integration
}

\author{
Jingli $\mathrm{Yu}$ \\ Graduate School \\ Jilin Sport University \\ Changchun, China
}

\author{
Wen Sun \\ Graduate School \\ Jilin Sport University \\ Changchun, China
}

\author{
Li Wang \\ School of Art \\ Taishan University \\ Taishan, China
}

\begin{abstract}
With the historical background of increasingly close cultural exchange between China and the West, this paper takes the innovative development of "Sinicization" of dance sport as the starting point of research and the evolution of the "Sinicization" of dance sport and the integration of national culture as the object of research to summarize and sort out the development history, development rules and main characteristics of dance sport in China through literature review method, systematic induction and expert interviews based on comparing the differences between Chinese and Western cultures. The combination of the Chinese local elements and dance sport is the trend of the times as well as a process of realizing the "Sinicization" of dance sport. The "Sinicization" of dance sport is not simply forcefully inserting the Chinese representative ethnic elements into dance sport, but subtly integrating them into dance sport on the basis of profound understanding and comprehension.
\end{abstract}

Keywords-cultural integration; dance sport; Chinese elements

\section{INTRODUCTION}

Dance sport originated in Western countries, and it itself contains strong Western cultural characteristics. Only by adding Chinese elements in dance sport clothing, music, movements, and choreography, can we truly realize the "Sinicization" of dance sport. From a national perspective, China's dance sport is developing toward various trends such as competition, socialization, artisry, and performization, and has established the "China dance sport Association" and "China dance sport Union" [ 1], to learn Western dance sport, imitate and absorb their high-level technical movements. Thus, the competitive level of China's dance sport has greatly increased. The integration of national culture into dance sport is an important breakthrough point for China in innovation, competition, and performance. From the perspective of society, material life and spiritual life support each other. Dance sport can promote the development of related sports industries and promote employment and entrepreneurship of some people. From this perspective, dance sport can promote economic development and promote people's material living standards [2]. In addition, dance sport culture has extensive sociality and mass feature, which is capable of cultivating people's taste and satisfying people's aesthetic needs. Therefore, we should integrate dance sport with ethnic culture.

\section{The EVOLUTION Process OF THE "SinIFICATION" IN DANCE SPORT}

This research is to explore the evolution of the Sinification of dance sport from three aspects of competition, socialization, and artistry, in order to explore the expression of Chinese elements in modern dance sport.

\section{A. The "Sinification" of Athletic Form of Dance Sport}

In 1989, China officially established the "China Ballroom Dance Federation" (renamed "China Ballroom Dance Society" after the 1990s) [3]. On May 3, 1991, the "China Sport Dance Sport Association" was established. China established the "China dance sport Training Center" in 1987, and hosted the "First National International Ballroom Dance Competition." Since then, China has organized some dance sport-related events each year. In 2002, the "China Ballroom Dance Society" and the "China Dance Sport Association" formed the "China Dance Sport Federation". China insists on dancing diplomacy with all the dancing countries. In recent years, China's dance sport has continuously introduced the world's top level of dance sport through the international platform in the development process and formed a development model of learning, digestion, absorption and innovation to promote the competition level [4].

\section{B. "Sinification" of Sports Dance and Social Integration}

1) Growing up in social environment: The development of any sport must play a role in serving the society. Dance sport itself has special social functions such as entertainment and fitness, cultivating one's taste, social 
interaction, and cultural inheritance, etc. Therefore, dance sport has the need of socialized development of sports. In addition, the types of dance sport are diverse and unique. The rhythm of modern dance is moderate, with soft soundtrack background music, which can not only cultivate temperament, but also cultivate a good body posture. It is the first choice for middle-aged and elderly people to participate in physical exercise. The Latin dance is passionate and enthusiastic, making the participants full of passion and forgetting troubles, which is especially suitable for young people and office workers. In addition, it can also achieve the effect of exercising each part of the participants. It can be seen that dance sport not only conforms to the social development environment, but also produces great social value. It promotes the physical and mental development of people, enriches social life, and improves people's interpersonal skills [5].

2) Demonstrating economic efficiency: The economic efficiency brought by dance sport is divided into two parts. One of them is the invisible value transformed from fitness [6]. As one of the national fitness programs, dance sport is not limited by age, venue and gender. It has a wide participation and a high fitness value. Sports dance cannot only improve the health level of exercisers, enhance physical fitness, but also cultivate high-quality labor talents to create intangible economic value for the society. Another part of the economic value brought by dance sport is the value directly generated by the dance sport industry. After the dance sport entered public views, there continuously emerged many training institutions with sports dance as the main teaching content in the society. In addition, performances or competitions with a commercial nature, to a certain extent, promoted the development of dance sport in China. The dance sport industry has formed a complete set of market economy system.

3) Promoting the popularization and promotion of sports dance by means of entertainment: Dance sport is a performing project with high entertainment and ornamental value. Both participants and admirers can cultivate their own beauty, appreciation level and expressiveness in this process [7]. 1) The manifestation of temperament beauty Dance sport originated from the Western aristocracy, and it shows its unique temperament through repeated practice of body shape. 2) The performance of strength beauty Dance sport is the fusion of sports and dance. The beauty it expresses is not only the combination of action and temperament. Through exercises, we can also feel the charm of sports. Strength is the support of dance sport. To complete the separate body exercise or a set of actions, we need to have enough physical agility and strength. 3) The performance of romantic charm beauty The charm expresses the dancer's strength, air, and spirit, which is the unity of the inner and outer of soul. Just as in the training of dance sport, participants are required to look up, lift the chest, hold the abdomen and erect waist, so that the whole body shape is straight, elegant and generous. On this basis, through the fusion of music, action and emotion, we can cultivate the romantic charm beauty.

\section{The "Sinification" of Artistic Expression of Dance Sport}

Through the bridge of "art", we can express our inner feelings and complete the process of emotional experience and communication with others. We can analyze the performance of "artistic" sports dance from the following three aspects:

The thought of "artistry" of dance sport: the thought is in the emotion, and the interpretation of sports dance from the perspective of art is bound to be based on the integration of emotional color. The "artistry" of dance sport is reflected in two aspects: sports skills and artistic performance. The "artistry" means of dance sport: Sports dance has the characteristics of "emotion inside and shape outside". The expression of soft and cultural connotation of dance sport is considered by the West to be true art. We can present the artistic nature of dance sport through the grasp of dance movements and the specific costumes, music and scenes during the practice or competition. The way of "artistry" of dance sport: dance sport reflects its unique artistic character through a variety of action combinations and colorful costumes. Russian literary theorist Plekhanov said: "Art can express human emotions and thoughts in an abstract way. This form of expression itself is artistic [8]."

1) "Sinification of dance sport music: The "Sinification" of music first reveals the cultural atmosphere of the Chinese nation. For example, dance sport music integrates into the composition of folk music in various competitions or teaching. Music is the soul of dance. To learn dance sport, we must first improve our musical quality. Music can create an atmosphere for the performance, and the dancers should first grasp the understanding of the music and the accuracy of the rhythm. The music of dance sport not only plays a key role in the rhythm, but also shows the importance in controlling dance movements. Both dancers should achieve a high degree of cooperation and tacit understanding in action, rhythm and emotion, which not only requires the players to have superb dance skills, but also depends on their grasp of music, so that the music and dance movements are coordinated and unified and can bring people the enjoyment of beauty. The rhythm of music in dance sport circulates in balance and the dancers will adjust the dance steps and formation according to the change of rhythm. The start and stop, advance and retreat and speed and so on of each movement should be completed according to music.

2) "Sinification" of dance sport costumes: In the big family of the Chinese people, all ethnic groups have developed unique national cultures in their respective development process. National costume is an important part of national culture and a symbol of national culture. Since ancient times, there have been the saying "know the flowers through smell, and know people by seeing the clothing", 
which shows that a unique pattern, Tentu, texture, craft, quality, style, design, and color matching all contain distinctive ethnic characteristics and the unique aesthetic taste as well as the simple and honest national spirit and temperament of a nation.

The costumes have the effect of beautification on the performance process. It can set off the temperament and spirit of the performers to add brilliance to the dance. For example, in modern dance competitions, in order to demonstrate the elegant and dignified temperament of women, they are usually dressed in evening dresses; most men are dressed in tuxedos that can very well embellish the slender figure of men and show their calm gentleman temperament. In the Latin dance competition, ladies wear irregular knee-high skirts or above the knees and the sling that highlights the figure. In addition, there are also grass skirts or long skirts that expose their backs. These colorful costumes can show the rich Latin style; men are psychological feelings. Therefore, the richness of dance sport costumes can bring colorful visual enjoyment to people. Dance sport costumes also have distinctive ethnic cultural features on the design elements. As a form of expression of culture, clothing reflects the cultural style of a nation from some aspects [9].

3) "Sinification of artistic Performances of Dance Sport: The Chinese-style art shows emphasizes dignity, elegance and generosity, which is also the biggest difference from Western dance. Dance sport is a sporting event with extremely high ornamental value and performance color. It gives people an enjoyment of art and beauty through wonderful performances. Practice shows that performance is one of the important elements for dance sport to present perfectly. In the process of dance sport performances, performers are usually rich in emotional expression. With their superb techniques, novel movements, extraordinary temperament, gorgeous styling, wonderful choreography, and delicate and soft performances, they embody the essence of dance sport. Among them, it is easy to overlook the choreography. The creation of dance sport is infinite. As long as you add some of your own ideas and use the three elements of movement, rhythm, and space to convey certain emotions, you will create different forms and styles of dance to make the performance of dance sport richer and more splendid.

\section{CONCLUSIONS AND SUGGESTIONS}

\section{A. Conclusions}

- Based on the spread rules and development characteristics of dance sport in China, it shows the inevitability of the perfection and development of "Sinicization" of dance sport. It has experienced the development and evolution of different eras, showing the continuous updating of the thought and content of the "Sinicization" of dance sport, which covers the dissemination of ideas and the development of culture.
- The evolution of "Sinicization" of dance sport is to explore the process, changes, and laws of development of dance sport in China. From the three aspects of competition, socialization and artistry, the author explores its evolution process and development law, and then through deep research, studies the manifestation of Chinese elements in the modern dance sport, in order to highlight the "Sinicized" national customs.

\section{B. Suggestions}

- To Strengthen cultural identity. The creation, costumes and music of dance sport emphasize the national characteristics and local characteristics to accelerate the process of "Sinicization" of dance sport.

- For example, we can nurture employees with the professional qualities of dance sport, and improve their own theoretical knowledge and technical level, so that each group of teachers or coaches who embark on the post is advanced talents with professional qualities. In addition, the training of sports dancers must be conducted in all aspects. We should not only improve the technical level, but also build a group of high-level sports dancers in terms of theoretical knowledge, scientific research ability, choreography ability, aesthetic ability, and teamwork.

\section{REFERENCES}

[1] Long Yinpei, Xu Erchong. Introduction to Dance [M]. Shanghai Literature and Art Publishing House, 1984, 129. 隆荫培,徐尔充.舞蹈 概论 $[\mathrm{M}]$.上海文艺出版社, 1984,129.

[2] Zhou Ying, Shen Ping. Effects of Physical Education Socialization in Colleges and Universities and realization approach $[\mathrm{J}]$. Sports \& Science 2002,(3):79-80. 周莹, 申萍.高校体育社会化的功效及实现 途径 $[J]$.体育与科学, 2002,(3):79-80.

[3] Ren Hai. On the reform of the International Olympic Committee[J]. China Sport Science, 2008,(7):3-25. 任海. 论国际奥委会的改革[J]. 体育科学, 2008,(7):3-25.

[4] Zhang Long, Yang Feng. Factors and Countermeasures Affecting the Development of Fitness and Entertainment Market of dance sport in China[J]. Journal of Hunan University of Arts and Science (Natural Science Edition, 2010,(3):87-90;94. 张龙,杨锋.影响我国体育舞蹈健 身娱乐市场发展的因素与对策 [J].湖南文理学院学报(自然科学 版),2010,(3):87-90;94.

[5] Li Benyou, Wang Qi et al. Integration and Shaping: University Image Design Based on CIS Theory[J]. University Academic, 2011,(2):18$23 ; 12$. 李本友,王琪等.整合与塑造:基于 CIS 理论的高校形象设计 [J].大学(学术版),2011,(2):18-23;12.

[6] Yin Fang. The Aesthetic Content and Manifestation of Dance Sport[D]. Jimei University, 2012. 殷放. 体育舞蹈的审美内容及其表 现形式[D].集美大学,2012.

[7] Tang Jingli. Research on the Operation Path and Investment and Financing Strategy of Hubei Sports Brand [D]. Wuhan Sports University, 2006. 唐景丽.湖北体育品牌运营路径及投融资策略研 究[D].武汉体育学院,2006.

[8] He Yu, Chen Linong. Exploration on the Development Trend and Countermeasures of China's Sports Dance from the Recent 2nd session of the Blackpool Dance Festival [J]. Sports, 2012, 22:19-20. 何宇,陈立农.从近 2 届黑池舞蹈节探讨我国体育舞蹈发展趋势及 对策[J].运动,2012,22:19-20. 
[9] Zhang Wei. Every Sports Dancer Has an Olympic Dream[J]. Intelligence, 2010, (12): 167-168. 张薇.每一个体育舞蹈人都有一个 奥运梦[J].才智,2010,(12):167-168. 